\title{
Pengembangan media pembelajaran remedial dengan aplikasi mobile learning pokok bahasan suhu dan kalor untuk meningkatkan prestasi belajar siswa SMA kelas $\mathrm{X}$
}

\author{
Dian Septa Puspitasari, Supriyono Koes Handayanto*, Widjianto \\ Universitas Negeri Malang, Jl. Semarang No. 5 Malang, Jawa Timur, Indonesia \\ *Penulis korespondensi, Surel: supriyono.koeshandayanto.fmipa@um.ac.id
}

Paper received: 01-08-2021; revised: 15-08-2021; accepted: 31-08-2021

\begin{abstract}
Abstrak
Tujuan dari penelitian dan pengembangan ini adalah mengembangkan media pembelajaran remedial dengan aplikasi Mobile Learning pokok bahasan suhu dan kalor dan menguji efektivitas media pembelajaran remedial dengan aplikasi Mobile Learning pokok bahasan suhu dan kalor untuk meningkatkan prestasi belajar siswa. Metode penelitian dan pengembangan yang digunakan adalah rancangan dari Brog and Gall sampai tahap ketujuh. Hasil penelitian ini berupa media pembelajaran remedial dengan aplikasi mobile learning. Berdasarkan hasil validasi ahli dan pengguna media tersebut data dikategorikan baik. Hasil implementasi menunjukkan bahwa penggunaan media pembelajaran remedial dengan aplikasi mobile learning menunjukkan peningkatan ( $N$-Gain) prestasi belajar siswa sebesar 0.65. Dengan demikian, secara umum produk pengembangan dapat membantu meningkatkan prestasi belajar siswa kelas X SMA, khususnya pada materi suhu dan kalor.
\end{abstract}

\section{Kata kunci: remedial; mobile learning; prestasi belajar}

\section{Pendahuluan}

Prestasi belajar siswa adalah hasil yang dicapai oleh siswa dari suatu aktivitas belajar yang dinyatakan dalam bentuk nilai atau angka. Dari suatu aktifitas belajar itulah terdapat berbagai faktor yang akan mempengaruhi hasil prestasi belajar, dan salah satunya dipengaruhi oleh seberapa dapat siswa penguasaan materi pelajaran pada setiap kegiatan belajar mengajar (KBM), maka dapat dikatakan bahwa besar kecilnya penguasaan materi siswa akan berperan dalam menentukan hasil prestasi belajar siswa.

Hasil analisis penguasaan materi soal fisika BSNP (2013) UN SMA tahun pelajaran 2012/2013 untuk wilayah Malang, materi suhu dan kalor memiliki persentase terendah kedua. Hal ini menunjukkan bahwa siswa kurang menguasai materi tersebut. Kurangnya penguasaan materi ini dapat menyebabkan siswa tidak tuntas kriteria ketuntasan minimal (KKM) yang berakibat pada rendahnya prestasi belajar siswa.

Dibutuhkan upaya untuk mendekatkan jarak antara siswa dengan prestasi tinggi dan siswa dengan prestasi rendah. Pendidik harus memberikan perhatian lebih dan menyediakan pembelajaran remedial untuk siswa dengan prestasi rendah (Lo, Wanga \& Yehb: 2004, Yang: 2010). Sesuai dengan Peraturan Menteri Pendidikan dan Kebudayaan RI No. 104 tahun 2014 siswa yang belum mencapai KKM harus mengikuti pembelajaran remedial.

Pembelajaran remedial yang selama ini ada dilapangan diantaranya dilakukan dengan ujian ulang tanpa adanya pembelajaran ulang dan pemberian tugas. Hal ini juga berkaitan dengan alokasi waktu saat diadakan pengakajian ulang, maka akan menggunakan waktu materi lain yang harus dipelajari. Temuan ini juga didukung hasil evaluasi kegiatan bimtek KTSP tahun 2008 dan 2009 yang dilaksanakan oleh Direktorat Pembinaan SMA juga sering 
ditemukan pendidik melakukan tes ulang terhadap peserta didik yang remedial tanpa melakukan perbaikan proses pembelajaran.

Menurut Astra, Umiatin, dan Ruharman (2012) Mobile learning dapat menjadi complement (pelengkap) dari materi pelajaran yang diberikan di kelas. Sebagai pelengkap, mobile learning dapat berfungsi sebagai penguat (reinforcement) atau remedial dan pengayaan (enrichment). West (2013) berpendapat, mobile learning mewakili sebuah cara untuk menyelesaikan beberapa masalah pendidikan di Amerika. Hasil penelitian Martin dan Ertzberger (2013) menunjukkan bahwa siswa yang menggunakan pembelajaran dengan mobile learning menunjukkan peningkatan prestasi belajar yang singnifikan.

Mobile learning adalah suatu bentuk pembelajaran menggunakan perangkat bersifat mobile seperti smartphone maupun tablet yang lebih ringkas, bisa dipelajari kapanpun dan dimanapun. Pertumbuhan beberapa proyek yang telah dilakukan menunjukkan bahwa teknologi mobile menyediakan media yang baik untuk memperpanjang kesempatan belajar pada siapa saja yang mungkin tidak mendapat akses kegiatan belajar mengajar dengan baik di sekolah. Hal ini juga di dukung dengan pergeseran paradigma belajar abad ke 21 yang menghendaki pembelajaran dapat mengintegrasikan teknologi dan informasi dalam pembelajaran.

Perkembangan perangkat bergerak (handphone) dengan sistem Android merupakan perangkat bergerak yang menunjukkan perkembangan pesat beberapa tahun terakhir. Menurut catatan yang dikeluarkan Asosiasi Telepon Seluler Indonesia (ATSI) pada tahun 2010, ada sekitar 160 juta penduduk Indonesia menjadi pelanggan layanan seluler sehingga diprediksi 60\% penduduk Indonesia sudah memiliki telepon selular. Menurut Polonia (2014) setelah menyebarkan angket di enam sekolah menengah atas di kota Malang, siswa SMA di Kota Malang kategori kepemilikan ponsel atau handphone sebagai berikut: sebesar $86 \%$ siswa menyatakan siswa mempunyai Android Phone, 5\% menyatakan siswa mempunyai windows phone, $8 \%$ menyatakan siswa mempunyai blackberry, dan 1\% menyatakan siswa mempunyai symbian phone. Selain itu, hasil survey awal terhadap 61 siswa SMA di Kota Malang, sebesar $85 \%$ siswa menyatakan siswa mempunyai android phone, 5\% menyatakan siswa mempunyai windows phone, $5 \%$ menyatakan siswa mempunyai blackberry, dan 5\% menyatakan siswa mempunyai symbian phone. Data ini menunjukkan bahwa terdapat peluang yang besar terhadap pengembangan penggunaan mobile learning.

Merujuk pernyataan diatas, menunjukkan bahwa salah satu bentuk remedial dapat menggunakan berbagai jenis media belajar untuk siswa. Hal ini juga didukung dengan perkembangan teknologi dan pemanfaatan kepemilikan telepon genggam oleh siswa. Pengembangan Media Pembelajaran Remedial dengan Aplikasi Mobile Learning Pokok Bahasan Suhu dan Kalor untuk Meningkatkan Prestasi Belajar Siswa Kelas X SMA dapat menjadi solusi solusi masalah keterbatasan tempat dan waktu tatap muka oleh guru dan siswa.

\section{Metode}

Penelitian menggunakan metode penelitian dan pengembangan dengan rancangan pengembangan Borg dan Gall (1983). Langkah-langkah pengembangan media pemebalajaran remedial dengan aplikasi mobile learning ada 7 langkah dari rancangan tersebut, yaitu (1) penelitian dan pengumpulan data, (2) perencanaan, (3) pengembangan draf produk, (4) uji 
lapangan tahap awal, (5) revisi produk utama, (6) uji pelaksanaan lapangan (implementasi), dan (7) penyempurnaan produk akhir.

Metode pengumpulan data yang digunakan untuk mengetahui validitas produk pengembangan yaitu metode angket dan hasil implementasi pre-test dan post-test one group desing. Instrumen yang digunakan untuk adalah angket dengan skala Likert oleh validator, instrumen angket penilaian terhadap pengguna oleh siswa dan instrumen tes yang telah divalidasi konten oleh tim ahli bersamaan dengan validasi produk. Data yang didapat berupa data kuantitatif dan kualitatif berdasarkan hasil validasi ahli dan pengguna. Hasil implementasi diperoleh nilai pre-test dan post-test untuk mengetahui peningkatan prestasi belajar siswa. Peningkatan prestasi belajar siswa dianalisis menggunakan $\mathrm{N}$-Gain.

Uji coba media pembelajaran remedial dengan aplikasi mobile learning pokok bahasan suhu dan kalor dilakukan tiga cara, yakni uji ahli, uji coba penilaian pengguna dan uji coba terbatas. Uji ahli melibatkan 3 ahli, yaitu satu dosen dan dua guru fisika SMA dimaksudkan untuk mengevaluasi kualitas produk yang dikembangkan. Uji coba penilaian terhadap pengguna dilaksanakan pada 13 siswa SMA kelas X SMAN 9 Malang untuk memperoleh respon terhadap pengguna. Kemudian uji coba terbatas (implemetasi) terhadap 21 siswa dimaksudkan untuk mengetahui peningkatan prestasi dari siswa yang melakukan pembelajaran remedial menggunakan aplikasi yang telah dikembangkan. Data ini diperoleh dari hasil pre-test dan post-test yang telah dikerjakan siswa. Setelah didapatkan nilai pre-test dan post-test selajutnya dianalisis peningkatan prestasi belajar siswa.

\section{Hasil dan Pembahasan}

Penelitian ini diawali dengan studi pendahuluan yang meliputi studi lapangan dan studi pustaka. Studi lapangan dilakukan untuk mengetahui kegiatan remedial yang selama ini dilakukan di sekolah. Pembelajaran remedial yang sudah dilakukan disekolah yaitu, siswa diberikan tugas dan ujian ulang tanpa ada pembelajaran ulang. Namun, siswa mengaku masih belum paham pada materi tersebut.

Peneliti juga melakukan penyebaran angket pada siswa tentang kepemilikkan smartphone oleh siswa. Berdasarkan penyebaran angket yang dilakukan diketahui bahwa hampir $85 \%$ siswa mempunyai smartphone berbasis android, namun penggunaanya masih belum maksimal. Sebagian besar siswa hanya menggunakan smartphone untuk bermain game dan social media. Studi pustaka digunakan untuk mengkaji literatur mengenai aplikasi mobile learning dan cara pengembangan produk yang akan dikembangkan.

Pengembangan media pembelajaran remedial dengan aplikasi mobile learning diawali dengan membuat draft susunan produk beserta instrumen validasi dan uji penilaian terhadap pengguna. Kemudian dikembangkan indikator, materi remedial, soal pilihan ganda. Materi yang dikembangkan merupakan materi suhu dan kalor. Hasil dari analisis KD. 3.8 dikembangkan 15 indikator ranah pengetahuan. Latihan soal yang dikembangkan bertipe objektif dan memiliki 5 pilihan jawaban. Pembuatan latihan soal didasarkan pada konsep taksonomi Bloom.

Data hasil validasi media pembelajaran remedial diperoleh dari rata-rata hasil validasi oleh validator, yaitu satu dosen dan dua guru fisika SMA kelas X MIA. Hasil rata-rata setiap aspek dari validasi media oleh validator dapat dilihat pada Tabel 1. 
Tabel 1. Hasil Rata-rata setiap Aspek dari Validasi Media oleh Validator

\begin{tabular}{llll}
\hline Aspek yang Dinilai & Rata-rata & Persentase (\%) & Krtiteria \\
\hline Kelayakan Materi & 3,44 & 86,11 & Baik \\
Efektivitas dan Efisiensi & 3,75 & 93,75 & Baik \\
Kemampuan untuk Dipelajari & 3,67 & 91,67 & Baik \\
Kamampuan untuk Diingat & 3,67 & 91,67 & Baik \\
\hline Rata-rata & 3,63 & 90,80 & Baik \\
\hline
\end{tabular}

Berdasarkan Tabel 1. diketahui bahwa dari keempat aspek yang dinilai mendapat kriteria baik dari hasil validasi ahli. Berdasarkan data hasil validasi, diketahui bahwa media pembelajaran remedial dengan aplikasi mobile learning yang telah disusun memiliki nilai rata-rata 3,63 dengan persentase sebesar 90,8 \%. Berdasarkan kriteria skala Likert, media yang telah disusun secara keseluruhan memiliki kriteria baik.

Data hasil uji penilaian terhadap pengguna ini berupa data kuantitatif dan kualitatif. Data kualitatif berupa saran pada bagian akhir angket, sedangkan data kuantitatif diperoleh berdasarkan penilaian terhadap angket dengan skala Likert. Pada uji penilaian terhadap pengguna terdapat empat aspek yang dinilai yakni, 1) halaman muka, 2) petunjuk penggunaan, 3) materi, dan 4) kebermanfaatan. Hasil analisis data uji penilaian terhadap pengguna memiliki nilai rata-rata 3,38 dengan persentase $84,61 \%$ memenuhi kriteria Baik.

Data peningkatan ( $N$-Gain) prestasi belajar siswa diperoleh dari perhitungan gain. Jumlah subjek uji adalah 21 siswa kelas X MIA. Rata-rata peningkatan ( $N$-gain) sebesar 0.65 dengan kriteria peningkatan sedang. Dapat disimpulkan penggunaan Media Pembelajaran Remedial dengan Aplikasi Mobile Learning dapat meningkatkan prestasi belajar siswa.

\section{Simpulan}

\subsection{Kesimpulan}

Media yang dikembangkan adalah media pembelajaran remedial dengan aplikasi mobile learning. Media pembelajaran remedial dengan aplikasi mobile learning dibuat menggunakan power point dengan bantuan iSpring dan Andaired untuk mengkonvert menjadi bentuk APK. Pada halaman Home terdapat beberapa menu, yaitu: 1) petunjuk, 2) kompetensi, 3) indikator, dan 4) profil. Tampilan media ditambahkan halaman yang sebelumnya tidak ada halaman atau nomor slide. Hal ini dilakukan untuk memberi kemudahan siswa dalam mempelajari dan mengingat materi yang telah dipelajari. Peletakkan nomor slide dengan ukuran dan bentuk juga disesuaikan agar dapat dengan mudah ditemukan oleh pengguna.

Bagian menu petunjuk penggunaan direvisi dengan mengubah background tulisan pada beberapa kotak yang terdapat tulisan. Background yang awalnya berwarna gelap diubah menggunakan warna yang lebih soft sehingga mudah dibaca dan semakin menarik untuk dilihat.

Media pembelajaran dengan aplikasi mobile learning dibuat dalam bentuk aplikasi android yang bisa dijalankan menggunakan smartphone atau tablet. 
Pemanfaatan telepon pintar menjadi salah satu media belajar siswa cara yang efektif dan efisien untuk selalu dipelajari kapan saja dan dimana saja. Produk juga menggunakan icon dan gambar yang mudah diingat oleg siswa.

Pada bagian awal penggunaan media pengguna memilih salah satu indikator yang sudah dikembangkan. Kemudian pengguna mengerjakan beberapa soal sesuai dengan indikator yang dipilih. Setelah selesai mengerjakan soal, akan muncul nilai hasil tes awal. Pada bagian ini pengguna yang belum meemenuhi KKM harus mempelajari media pembelajar remedial yang sudah disiapkan. Tahap selanjutnya adalah siswa mengerjakan tes setelah menerima materi remedial dan akan mendapatkan nilai hasil tes. Tahap-tahap tersebut dilakukan pada semua indikator yang telah dikembangkan, ketika pada tes awal pengguna sudah lulus maka pengguna tidak harus membuka materi remedial. Dengan demikian masing-masing pengguna akan mempelajari materi yang berbeda sesuai dengan kesulitannya.

Berdasarkan hasil analisis kuantitatif hasil validasi dan uji penilaian terhadap pengguna produk menunjukkan bahwa modul memenuhi kriteria baik sehingga layak untuk dijadikan media pembelajaran remedial. Hasil implementasi juga menunjukkan bahwa penggunaan media pembelajaran remedial dengan aplikasi mobile learning menunjukkan peningkatan ( $N$-Gain) dalam kriteria sedang. Kriteria hasil validasi baik dan hasil peningkatan sedang menunjukkan bahwa secara umum produk dapat membantu meningkatkan prestasi belajar siswa kelas X SMA khususnya pada materi suhu dan kalor. Oleh karena itu, tujuan penelitian dan pangembangan sudah tercapai. Peneliti sudah dapat mengembangkan media pembelajaran remedial dengan aplikasi mobile learning pokok bahasan suhu dan kalor yang dapat meningatkan prestasi belajar siswa.

Pada pelaksanaannya produk yang dikembangkan sudah dapat meningkatkan prestasi belajar siswa, akan tetapi produk ini juga memiliki kelemahan, Kelemahan produk berkaitan dengan ukuran font dan gambar pada soal tes yang dirasa kurang besar dan tidak bisa diperbesar lagi karena keterbatasan kemampuan aplikasi yang digunakan pengembang. Hasil tes yang terkirim pada e-mail pengembang juga belum dapat diketahui pengirimnya hal ini karena keterbatasan kemampuan aplikasi yang digunakan oleh pengembang.

\subsection{Saran}

Berdasarkan hasil penelitian dan pengembangan saran yang dapat dikemukakan adalah pengembangan latihan soal pada ranah pengetahuan yang bertingkat tiap indikator. Pengembangan selajutnya dapat dikembangkan media yang bisa merekam identitas pengguna setelah menjawab soal agar guru dapat langsung memberikan balikan yang cepat. Dan pengembangan pada pokok bahasan yang lain. Saran yang diberikan untuk menyebarluaskan hasil penelitian melalui publikasi melalui seminar, blog, forum, web maupun google play. 


\section{Daftar Rujukan}

Astra, I. M. (2012). Aplikasi mobile learning fisika dengan menggunakan Adobe Flash sebagai media pembelajaran pendukung. Jurnal Pendidikan dan Kebudayaan, 18(2), 174-180.

Badan Standar Nasional Pendidikan (BSNP). (2013). Persentase Penguasaan Materi Soal Fisika Ujian Nasional SMA/MA Tahun Pelajaran 2012/2013.

Borg, W. R., \& Gall, M. D. (1983). Chapter 12. The methods and tools of observational research. Educational Research: An introduction (4th Edition). Longman: New York.

Direktorat Pembinaan SMA. (2010). Petunjuk Teknis Pembelajaran Tuntas, Remedial, dan Pengayaan di SMA

Lo, J. J., Wang, H. M., \& Yeh, S. W. (2004). Effects of confidence scores and remedial instruction on prepositions learning in adaptive hypermedia. Computers \& Education, 42(1), 45-63.

Martin, F., \& Ertzberger, J. (2013). Here and now mobile learning: An experimental study on the use of mobile technology. Computers \& Education, 68, 76-85.

Polonia, B. S. E. (2014). Pengembangan aplikasi kamus fisika berbasis android sebagai alternatif sumber belajar mandiri siswa kelas X pokok bahasan fluida statis dan kalor (Doctoral dissertation, Universitas Negeri Malang).

Yang, Y. F. (2010). Developing a reciprocal teaching/learning system for college remedial reading instruction. Computers \& Education, 55(3), 1193-1201. 